\title{
Tantangan ALKI dalam Mewujudkan Cita-cita Indonesia sebagai Poros Maritim Dunia
}

\author{
Ismah Rustam \\ Universitas Mataram
}

\begin{abstract}
Making Indonesia the world's maritime axis is the vision promoted by Joko Widodo (Jokowi) to the next five years of his tenure after his victory in the presidential election 2014. This goal is in line with the struggle of Sukarno, who wanted Indonesia to become a strong and independent maritime country at the time. His desire was rooted from the awareness of Indonesia's strategic position as well as maritime potentials that the country have. The main objective of Jokowi's idea is to boost Indonesia's economic growth and equitable development which is focused on the marine sector. The development of maritime force is not without obstacles. The policy to build Indonesian Archipelagic Sea Lanes (ALKI) makes Indonesia as an 'open country'. Until now, a wide range of foreign shipping and airlines are freely passing cut of Indonesia. Security threats on three ALKI lines would become the challenge for the Indonesian government towards the maritime axis.
\end{abstract}

Keywords: maritime axis, ALKI, Indonesia

\begin{abstract}
Abstrak
Menjadikan Indonesia sebagai poros maritim dunia adalah visi yang diusung oleh Joko Widodo (Jokowi) untuk masa jabatan lima tahun ke depan sejak kemenangannya pada pemilu presiden 2014. Cita-cita ini sejalan dengan perjuangan Sukarno yang menginginkan Indonesia menjadi negara maritim yang kuat dan mandiri pada masanya. Keinginan ini berangkat dari kesadaran akan posisi strategis dan potensi bahari yang dimiliki Indonesia. Tujuan utama dari gagasan Jokowi ialah mendongkrak pertumbuhan ekonomi Indonesia serta pemerataan pembangunan yang difokuskan pada sektor laut. Pembangunan kekuatan maritim bukannya tanpa hambatan. Kebijakan membentuk Alur Laut Kepulauan Indonesia (ALKI) menjadikan Indonesia sebagai negara 'terbuka'. Hingga kini, berbagai pelayaran dan penerbangan asing dengan bebas berlalu lalang memotong wilayah Indonesia. Ancaman keamanan pada tiga jalur ALKI menjadi tantangan bagi pemerintah Indonesia dalam menuju cita-cita poros maritim.
\end{abstract}

Kata-kata kunci: Poros Maritim, ALKI, Indonesia 


\section{Pendahuluan}

Cita-cita Indonesia menjadi poros maritim dunia semakin mengemuka ketika Joko Widodo (Jokowi) secara resmi menggantikan Susilo Bambang Yudhoyono pada bulan Oktober 2014. Cita-cita poros maritim menjadi visi utama yang diusung untuk periode lima tahun pemerintahan presiden ke tujuh Indonesia tersebut. Indonesia merupakan negara yang memiliki kurang lebih 17.506 pulau yang tersebar dalam luas lautan yang mencapai 5,8 juta kilometer persegi. Indonesia berada pada posisi silang yang sangat strategis. Posisi ini menguntungkan karena letak strategisnya di persimpangan dua samudera yaitu Samudera Hindia dan Pasifik serta dua benua yaitu benua Asia dan Australia. Keuntungan ini menjadi modal dasar keinginan pemerintah untuk menjadikan Indonesia sebagai poros maritim dunia. Sebagai langkah awal, misalnya, pada 13 November 2014 Joko Widodo menyampaikan visi kelautan dalam KTT Asia Timur (East Asian Summit) di Myanmar (Tempo, 2014). Dengan gagasan tersebut, disampaikan bahwa Indonesia akan memiliki peran besar dalam berbagai bidang. Dalam bidang ekonomi, Indonesia akan memegang peranan penting dalam perdagangan dunia, karena 40 persen perdagangan internasional melalui perairan Indonesia. Dalam bidang keamanan letak strategis Indonesia sedikit banyak menjadi faktor dalam berkembangnya berbagai isu keamanan. Seperti perselisihan mengenai batas maritim atau tindak kejahatan yang terjadi di laut. Teritorial yang mendukung sebagai wilayah transit juga menjadi ladang maraknya kegiatan ilegal yang melanggar hukum.

Kesungguhan Indonesia menjadi poros maritim dunia setidaknya dapat dilihat dari tiga hal, yaitu adanya keinginan kuat pemerintah untuk membangun tol laut. Rencana pembangunan tol laut ialah untuk menjamin konektivitas antar pulau, pengembangan industri perikanan dan perkapalan, perbaikan transportasi laut dan pembangunan pelabuhan. Lalu, promosi jargon Indonesia sebagai poros maritim dunia dilakukan dalam berbagai pertemuan dan perhelatan baik secara bilateral, regional maupun multilateral. Kemudian, terdapat wacana peningkatan kekuatan armada laut guna menyeimbangkan situasi keamanan di seluruh wilayah perairan Indonesia.

Kenyataannya, Indonesia memiliki keunggulan di bidang maritim yang tidak dimiliki oleh negara lain. Hal ini merupakan sebuah kekuatan yang mampu membawa Indonesia beranjak dari sebuah negara sedang berkembang menjadi negara maju. Oleh karena itu, pengelolaan wilayah teritoral laut Indonesia hendaknya menjadi konsentrasi pemerintah. 
Dengan harapan akan menjadi daya tawar dalam kebijakan luar negeri Indonesia ke depannya. Hal tersebut juga dirumuskan oleh seorang pakar strategi keamanan Connie Rahakundini (2015), bahwa kekuatan sebuah negara dapat dibentuk dari hasil penjumlahan faktor-faktor seperti kekuatan ekonomi, militer, dan critical mass. Hasil dari penjumlahan itu akan dikalikan dengan strategi negara dan cita-cita atau kepentingan nasional. Selanjutnya, keseluruhan jumlah ini akan dibagi dengan faktor pengaruh atau ancaman kekuatan negara (external super power) khususnya di lingkungan sekitar.

Terkait dengan gagasan poros maritim yang mengedepankan peran laut Indonesia, tak bisa dilepaskan dari sederet masalah krusial yang nampaknya akan menjadi penghambat dalam menuju cita-cita tersebut. Masalah klasik seperti ancaman keamanan laut belum dapat terselesaikan hingga kini. Kepentingan teritorial dari negara lain baik ekonomi, politik, dan keamanan juga bisa menjadi penghalang bagi pemerintah Indonesia. Belum lagi tantangan dari banyaknya pelanggar hukum yang pada akhirnya merugikan Indonesia.

Dalam konteks tersebut, tulisan ini mengangkat dinamika dan tantangan pada jalur lalu lintas internasional di wilayah Indonesia, Alur Laut Kepulauan Indonesia (ALKI), dalam menuju cita-cita poros maritim dunia. Jalur ALKI menjadi representasi dari luasnya wilayah perairan yurisdiksi nasional yang berkaitan erat dengan status Indonesia sebagai sebuah negara maritim. ALKI sendiri merupakan suatu wilayah terbuka yang membagi Indonesia dalam empat kompartemen strategis dan tercatat menimbulkan beragam permasalahan di laut. ALKI terbentuk setelah United Nations Convention on the Law of the Sea (UNCLOS) tahun 1982 (yang diratifikasi dengan UU No. 17 Tahun 1985) dan dinyatakan sebagai hukum positif internasional sejak 16 November 1994 telah mengakui hak Indonesia sebagai Archipelagic State (Wahyono, 2007:89). Pengakuan tersebut muncul karena Indonesia memiliki garis pantai sepanjang 81.000 kilometer dan luasnya bentang landas kontinen. UNCLOS mengatur seluruh kewenangan negara pantai dan negara kepulauan terhadap wilayah laut (laut teritorial, zona tambahan, zona ekonomi eksklusif, dan landas kontinen). Dukungan status juga diperkuat karena Indonesia memiliki potensi sumber daya laut hayati dan nonhayati yang berlimpah. Dipandang dari segi estetika, memiliki nilai yang sangat tinggi bagi pariwisata bahari. Dari sisi ekonomi dan industri, sangat menguntungkan bagi alur transportasi laut dan daerah penangkapan hasil laut. Sementara dari segi geografis, terletak pada posisi 
silang antara dua samudera yang merupakan jalur penting perdagangan dunia. Konsekuensi logis dari sisi geografis ini, perairan Indonesia memiliki nilai politik dan strategi keamanan yang sangat penting bagi negara lain.

Visi menjadi poros maritim dunia terus menjadi prioritas utama dalam pekerjaan pemerintah Indonesia saat ini. Untuk mencapainya membutuhkan waktu dan proses yang cukup lama. ALKI menjadi salah satu bagian yang berpengaruh dalam memperjuangkan cita-cita ini. Apakah ALKI akan menjadi peluang bagi Indonesia dalam menuju poros maritim dunia atau justru akan menimbulkan banyak ancaman/tantangan yang memperlambat pemerintah merealisasikan gagasan tersebut? Tulisan ini akan mencoba menjawab pertanyaan tersebut.

\section{Cita-cita Bangsa Indonesia Sebagai 'Poros Maritim Dunia'}

Jauh sebelum gagasan Poros Maritim muncul sebagai visi yang diusung pemerintahan Jokowi, cita-cita menjadikan Indonesia sebagai negara maritim telah dicetuskan terlebih dahulu oleh Sukarno. Berangkat dari Deklarasi Djuanda, Indonesia akhirnya diakui sebagai Archipelagic State atau negara kepulauan oleh komunitas internasional. Negara kepulauan merupakan konsep wilayah yang utuh yang meliputi kesatuan seluruh gugusan pulau-pulau dan laut di dalamnya. Pengakuan konsep Archipelagic State ini diperjuangkan dengan berbagai upaya diplomatik selama bertahun-tahun di bawah kepemimpinan Sukarno hingga Suharto. Sukarno begitu memahami potensi Indonesia terutama pada kekuatan maritim yang didukung oleh letak geografis. Sejarah nusantara mencatat bahwa pejuang Indonesia selalu berjaya di laut. Sebut saja kerajaan Sriwijaya dan Majapahit yang menggunakan kekuatan laut untuk meluaskan kekuasaan dan menguasai perdagangan nusantara (Prasetyono, 2008:350). Menjadi sebuah pelajaran penting bagi Indonesia untuk menyadari bahwa laut merupakan aset strategis yang harus dijaga.

Menurut Sukma (2014), gagasan poros maritim dapat dipahami dalam tiga makna. Pertama, poros maritim dapat dilihat sebagai sebuah cita-cita mengenai Indonesia yang ingin dibangun. Poros maritim dapat dikatakan sebagai sebuah seruan besar untuk kembali ke jati diri Indonesia atau identitas nasional sebagai sebuah negara yang dengan potensi lautnya, yang diharapkan akan mewujud dalam bentuk Indonesia sebagai kekuatan maritim yang bersatu (unity), sejahtera (prosperity), dan berwibawa (dignity). Kedua, poros maritim juga dapat dipahami sebagai sebuah doktrin, yang memberi arahan mengenai tujuan bersama. Sebagai 
doktrin, pemerintah mengajak bangsa Indonesia melihat dirinya sebagai 'Poros Maritim Dunia'. Ketiga, gagasan poros maritim Jokowi tidak berhenti pada level abstraksi dan konseptualisasi. Gagasan itu menjadi operasional ketika platform Jokowi memuat sejumlah agenda konkret yang ingin diwujudkan dalam pemerintahannya ke depan.

Sebagai langkah awal untuk menjalankan visi poros maritim, Jokowi merancang lima agenda yang diperuntukkan bukan hanya kepada jajaran pemerintah saja tetapi seluruh lapisan masyarakat (Tempo, 2014). Pertama, membangun kembali budaya maritim Indonesia dimana identitas, kemakmuran, dan masa depan bangsa sangat ditentukan oleh pengelolaan laut. Kedua, bangsa Indonesia wajib untuk menjaga dan mengelola sumber daya laut. Ketiga, memprioritaskan pengembangan infrastruktur dan konektivitas maritim salah satunya dengan membangun tol laut, pelabuhan laut dalam, industri perkapalan, dan pengembangan pariwisata maritim. Keempat, melaksanakan diplomasi maritim. Kelima, membangun kekuatan pertahanan maritim. Gagasan poros maritim menjadi sangat tepat dikemukakan saat ini mengingat kondisi perekonomian Asia Pasifik sedang dalam perkembangan pesat. Indonesia harus mampu memanfaatkan situasi tersebut karena lautan Indonesia menjadi jembatan utama dalam dinamika interaksi antar negara.

Gagasan Indonesia sebagai poros maritim dunia menjadi sebuah tujuan besar untuk masa depan bangsa, terutama dalam pembangunan dan pemerataan ekonomi di seluruh wilayah Indonesia mengingat Indonesia adalah negara kepulauan yang berada di wilayah strategis dan memiliki sumber daya alam laut yang besar. Namun pengakuan komunitas internasional bahwa Indonesia sebagai sebuah negara kepulauan saja tidaklah cukup, karena agenda utama bangsa Indonesia ialah menjadi sebuah negara maritim. Menurut pakar Hukum Laut Hasjim Djalal, negara maritim tidak sama dengan negara kepulauan. Negara maritim adalah negara yang mampu memanfaatkan potensi lautnya, sekalipun negara tersebut mungkin tidak punya banyak laut, seperti negara pantai. Tetapi harus mempunyai kemampuan teknologi, ilmu pengetahuan, peralatan, dan lain-lain untuk mengelola dan memanfaatkan laut tersebut, baik ruangnya, kekayaan alamnya maupun letaknya yang strategis (Victor, 2014). Oleh sebab itu, dari banyaknya negara kepulauan atau negara pulau serta negara pantai yang hingga saat ini belum menjadi negara maritim secara utuh karena ketidakmampuan negara itu dalam memanfaatkan lautan yang berada di wilayah teritorialnya. Sementara itu, proses panjang menuju poros maritim dunia 
harus dimulai dengan langkah pertama yaitu mengubah Indonesia dari status negara kepulauan menjadi negara maritim.

Seluruh jajaran pemerintah dan masyarakat hendaknya juga memberikan perhatian untuk pengembangan, pemanfaatan, dan pemeliharaan potensi kelautan Indonesia. Menurut Rosihan Arsyad, Indonesia diramalkan akan menjadi negara besar dan menjadi mesin pertumbuhan Asia, serta menjadi salah satu jajaran negara-negara ekonomi terbesar dunia. Hal ini bisa dilihat pada 2007, perdagangan Indonesia mencakup ekspor 114.100.890.751 dolar AS untuk 342.773.698 ton komoditi. Menurut Indonesia Central Statistic Agency nilai ini naik dua kali lipat pada tahun 2012. Oleh karena itu, wajar jika Robert Kaplan menyebutkan posisi Indonesia sebagai negara supra strategic (Arsyad, 2010:170). Besarnya peluang ekonomi dihasilkan bukan hanya dari sektor tanah melainkan dari potensi maritim yang meliputi seluruh wilayah perairan di tanah air. Selama ini pemerintah mempunyai orientasi pada pembangunan berbasis daratan sehingga kita lebih dikenal sebagai negara agraris, maka saat ini orientasi pembangunan ke depan harus memprioritaskan pada sektor kelautan demi terwujudnya cita-cita poros maritim dunia.

Pemerintah memanfaatkan berbagai momen Internasional sebagai ajang untuk menunjukkan wawasan kelautan bangsa dan peran Indonesia sebagai negara maritim kepada dunia Internasional. Pada tahun 2009 misalnya, telah dilaksanakan World Ocean Conference di Manado (Setneg, 2009), untuk kali pertama Indonesia menjadi tuan rumah dari agenda resmi berbagai negara, organisasi dunia seperti PBB dan UNEP, serta lembaga-lembaga internasional seperti WWF. Acara ini merupakan perhelatan akbar yang secara khusus memberi perhatian pada laut dan sumberdaya di dalamnya. Bagi Indonesia, di samping untuk menunjukkan wawasan kemaritiman, kegiatan ini juga merupakan momentum untuk meningkatkan kerjasama internasional demi optimalisasi, pengembangan serta pelestarian sumberdaya laut. Gagasan negara maritim Indonesia merupakan aktualisasi wawasan nusantara untuk memberi gerak pada pola pikir, pola sikap dan pola tindak bangsa Indonesia. Landasan konsepsional wawasan nusantara menjadi pilar utama yang telah memberikan hak luar biasa di laut, darat maupun udara serta menyatakan bahwa wilayah nusantara adalah satu kesatuan politik, ekonomi, sosial budaya dan keamanan. Konsep negara maritim akan mendorong tercapainya cita-cita sebagai poros maritim dunia. Bangsa Indonesia harus meningkatkan segala kemampuan untuk menjadi bangsa 
yang modern dan mandiri terutama dalam teknologi kelautan dan kedirgantaraan. Pancasila dan UUD 1945 menjadi landasan utama untuk menuju cita-cita tersebut karena kedua landasan ini telah mewadahi seluruh aspirasi bangsa Indonesia.

\section{Gambaran Alur Laut Kepulauan Indonesia (ALKI)}

Pasca penetapan status Indonesia sebagai negara kepulauan, kewajiban pemerintah Indonesia terhadap status tersebut diatur dalam Pasal 46-53 UNCLOS 1982. Indonesia dapat menentukan alur laut untuk lintas kapal dan pesawat udara bagi negara asing yang akan lewat secara terus-menerus dan langsung serta secepat mungkin melalui atau di atas perairan kepulauannya dan teritorial yang berdampingan dengannya (Budiman, 2010). UNCLOS Pasal 47 menyatakan bahwa negara kepulauan dapat menarik garis pangkal lurus kepulauan (arhipelagic baselines) dimana aturan ini sudah ditransformasikan ke dalam UU No. 6 Tahun 1996 tentang perairan Indonesia dan disusul PP No. 37 Tahun 2002 tentang hak dan kewajiban kapal dan pesawat udara asing dalam melaksanakan hak lintas alur laut kepulauan melalui alur laut kepulauan yang ditetapkan. PP No. 38 Tahun 2002 juga menyempurnakan aturan tentang daftar koordinat geografis titik-titik garis pangkal kepulauan Indonesia (Presiden RI, 2002). Pembentukan ALKI juga berlandaskan UU No. 17 Tahun 1985 (BPKP, 2009). Beberapa undang-undang yang telah disahkan oleh pemerintah ini memuat segala ketentuan dan kesepakatan yang telah diputuskan pada konvensi PBB 1982.

Definisi ALKI dan negara kepulauan dapat dilihat pada dasar perumusan RUU Pengelolaan Ruang Udara Nasional berdasarkan UU No. 6 Tahun 1996 tentang Perairan Indonesia, negara kepulauan Indonesia dan Alur Laut Kepulauan, diantaranya; 1) Negara Kepulauan adalah negara yang seluruhnya terdiri dari satu atau lebih kepulauan dan dapat mencakup pulau-pulau lain; 2) Kepulauan adalah suatu gugusan pulau, termasuk bagian pulau dan perairan di antara pulau-pulau tersebut, dan lain-lain wujud alamiah yang hubungannya satu sama lain demikian eratnya sehingga pulau-pulau, perairan, dan wujud alamiah lainnya itu merupakan satu kesatuan geografi, ekonomi, pertahanan keamanan, dan politik yang hakiki, atau yang secara historis dianggap sebagai demikian; 3) Perairan Indonesia adalah laut teritorial Indonesia beserta perairan kepulauan dan perairan pedalamannya; 4) Alur laut kepulauan adalah alur laut yang dilalui oleh kapal atau pesawat udara asing di atas alur laut tersebut, untuk melaksanakan pelayaran dan penerbangan dengan cara 
normal semata-mata untuk transit yang terus menerus, langsung dan secepat mungkin serta tidak terhalang melalui atau di atas perairan kepulauan dan teritorial yang berdampingan antara satu bagian laut lepas atau Zona Ekonomi Ekslusif Indonesia dan bagian laut lepas atau Zona Ekonomi Eksklusif Indonesia lainnya (BPKP, 1996).

Definisi di atas menegaskan status Indonesia sebagai sebuah negara kepulauan yang memiliki luas wilayah perairan yang lebih besar dari pada daratan dengan hak penuh untuk memanfaatkan segala potensi yang terkandung didalamnya. Mengingat persebaran pulau-pulau baik yang berada di wilayah perairan dalam maupun perbatasan Indonesia yang berada pada jalur ALKI I, ALKI II dan ALKI III maka prospek penjagaan keamanan laut wajib ditingkatkan dengan menyesuaikan luas wilayah yang dimiliki. Setiap tahunnya, ketiga jalur pelayaran resmi tersebut semakin ramai dilalui oleh kapal-kapal besar dari benua Asia ke benua Amerika melalui Pasifik maupun sebaliknya (Karim, 2010).

Secara oceano-geografis Indonesia memiliki empat dari tujuh jalur pelayaran internasional lalu lintas damai, yaitu Selat Malaka, Selat Sunda, Selat Makassar-Lombok dan Selat Ombai-Wetar, di samping tiga lainnya yaitu Terusan Suez di Mesir, Terusan Panama serta selat Gibraltar yang terletak diantara Spanyol dan Maroko (Sitohang et al., 2008:30). Empat dari tujuh jalur pelayaran Internasional yang terdapat di perairan Indonesia tersebut merupakan jalur lalu lintas pelayaran paling ramai dan tepat berada pada jalur ALKI.

Kapal asing yang sedang melakukan pelayaran internasional dalam melaksanakan hak lintas melalui ALKI baik kapal niaga maupun kapal perang dapat melintas tanpa harus meminta izin terlebih dulu kepada pemerintah Indonesia. Termasuk kapal selam asing juga dapat melintas tanpa harus muncul dipermukaan laut, namun hanya dikhususkan pada tiga alur laut yang telah disepakati. Jika melewati alur yang telah ditentukan maka dianggap telah melakukan pelanggaran. Berikut gambaran peta tiga Alur Laut Kepulauan Indonesia yang telah disetujui dan disahkan oleh pemerintah Indonesia pada tahun 2002. 


\section{Gambar 1. Jalur ALKI yang telah disahkan oleh pemerintah Indonesia}
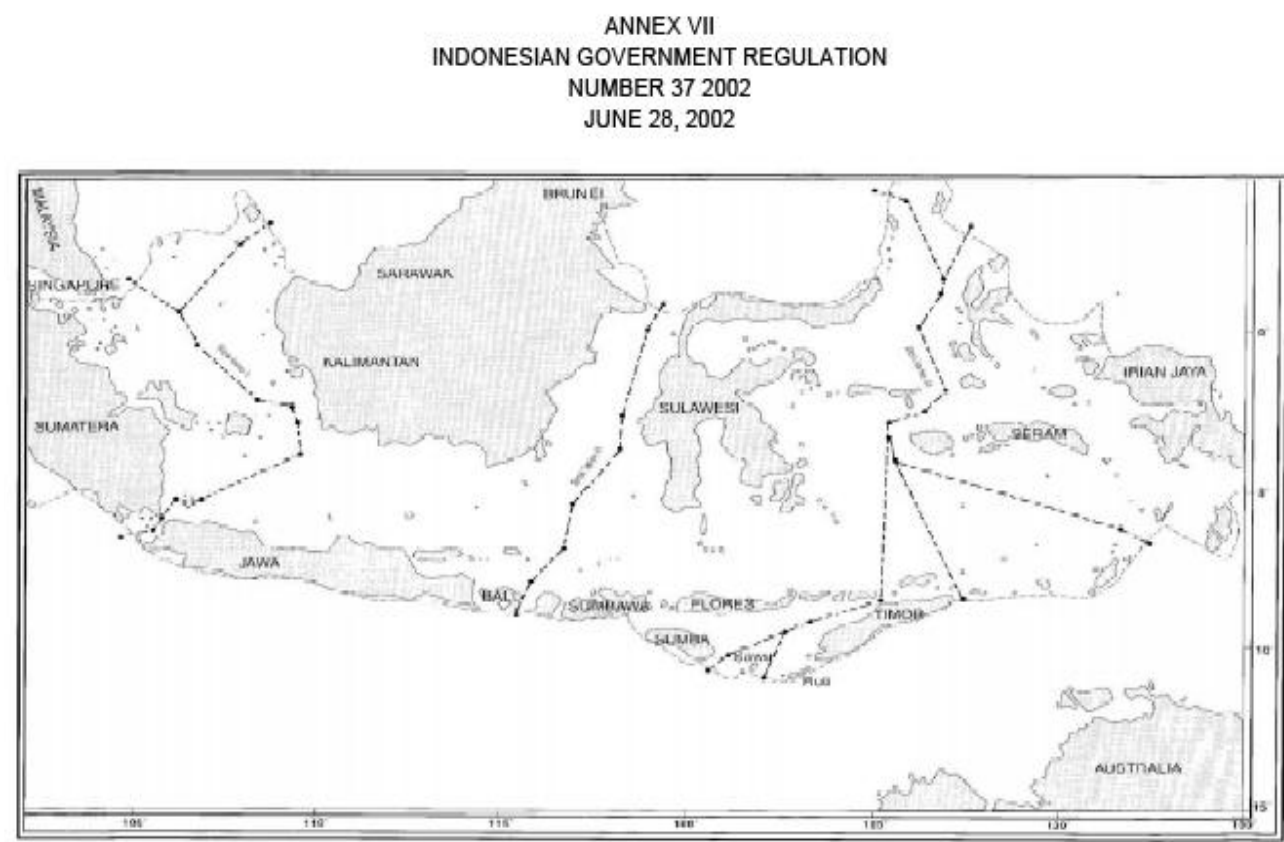

INDONESIAN ARCHIPELAGIC SEA LANES I, II AND II
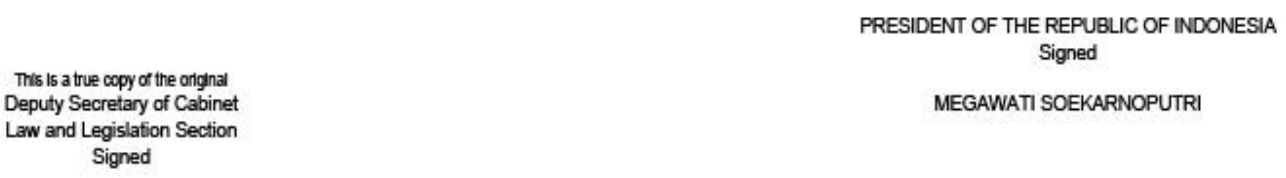

Sumber: IMO, 2010

Peta yang menunjukkan tiga jalur ALKI di atas telah disepakati juga dalam Internasional Maritim Organization dengan rincian sebagai berikut: 1) ALKI I, Selat Sunda, Selat Karimata, Laut Natuna dan Laut Cina Selatan; 2) ALKI II, Selat Lombok, Selat Makasar, dan Laut Sulawesi; 3) ALKI III-A, Laut Sawu, Selat Ombai-Wetar, Laut Banda (Sebelah Barat Laut Buru), Laut Seram (Sebelah Timur Pulau Mongole), Laut Maluku dan Samudera Pasifik; 4) ALKI III-B, Laut Timor, Selat Leti, Laut Banda (Barat Laut Buru), selanjutnya ke ALKI III-A; dan 5) ALKI III-C, Laut Arafuru, Laut Banda (Barat Pulau Buru) selanjutnya terus ke utara menyambung ALKI III-A (Sitohang, 2007).

Dengan dibukanya ALKI I, II, dan III tentu membuka pula peluang kehadiran berbagai konsekuensi keamanan di perairan Indonesia. Ketiga jalur strategis tersebut sangat berarti bagi negara lain. Jalur itu digunakan oleh banyak negara untuk menopang kegiatan ekonomi mereka. 
Perdagangan dan transportasi internasional kian meningkat menempatkan laut Indonesia memegang peranan penting sebagai penghubung antar pulau dan antar negara.

\section{Tantangan wilayah Alur Laut Kepulauan Indonesia (ALKI)}

Laut Indonesia merupakan jalur pelayaran tersibuk di dunia. Menurut sumber dari Review of Maritime Transport tahun 2008 diterbitkan oleh The United Nations Conference on Trade and Development (UNCTAD), perdagangan melalui jalur laut akan mengalami peningkatan sebesar 44 persen di tahun 2020 dan akan mencapai dua kali lipat pada tahun 2031 (Irewati, 2011:185). Pembentukan ALKI menjadi jalan untuk memudahkan negara pihak yang bersangkutan dalam pelaksanaan hak dan kewajiban untuk melintas di wilayah Indonesia. Bagi Indonesia selaku negara yang mempunyai kedaulatan teritorial seharusnya kebijakan ini memudahkan pemerintah karena dari sekian banyak celah perairan di Indonesia hanya tiga jalur ini yang dibuka secara resmi sehingga dapat menjadi prioritas utama. Sebaliknya bagi negara yang kapalnya ingin melintas di jalur tersebut wajib mengikuti seluruh prosedur yang telah ditentukan. Intensitas pelayaran yang semakin banyak mendorong pula peningkatan permasalahan di laut. Hingga kini persoalan keamanan laut belum menemukan solusi yang tepat. Bahkan senantiasa menjadi bahasan dalam berbagai forum guna menemukan jalan keluar dari masalah ini.

Ancaman keamanan laut ini dapat ditinjau dari dua model; isu keamanan tradisional maupun isu keamanan non-tradisional. Ancaman keamanan tradisional yang melibatkan aktor negara kini tergeser oleh maraknya isu keamanan non-tradisional. Namun bukan berarti isu keamanan tradisional hilang begitu saja. Justru Indonesia perlu lebih waspada karena ancaman ini dapat muncul sewaktu-waktu. Mengingat pemerintah Indonesia masih punya segudang pekerjaan rumah baik masalah batas laut maupun batas kontinen. Berdasarkan catatan TNI Angkatan Laut, pada tahun 2007, dalam kurun waktu setahun saja terhitung terjadi 94 kali pelanggaran yang dilakukan oleh kapal perang Malaysia di wilayah perairan Indonesia (Usman dan Isnawita, 2009:23). Aksi-aksi provokasi Malaysia menjadi ancaman yang dapat mengganggu stabilitas keamanan laut.

Ancaman keamanan non-tradisional lebih sering disebut sebagai isu transnasional. Aktor kejahatan transnasional umumnya adalah kelompok terorganisir yang tujuan utamanya adalah mendapatkan uang baik secara legal maupun tidak legal dengan menjual barang dagangan 
apapun yang dapat memberikan keuntungan maksimal dengan resiko sesedikit mungkin. Kegiatan mereka meliputi jual beli senjata, narkotika, kejahatan kekerasan, pemerasan, pencucian uang, pornografi, prostitusi, kejahatan komputer, ekologi dan sebagainya yang melintasi batas negara (Cipto, 2007:224). Isu kejahatan transnasional yang dihadapi Indonesia dapat dikategorikan menjadi tiga: Pertama, gangguan keamanan di laut contohnya penyelundupan kayu, bahan bakar minyak, pasir, dan pencurian ikan. Kedua, gangguan keamanan di udara contohnya pembajakan di udara, sabotase, pengintaian terhadap wilayah Indonesia dan lain-lain. Ketiga, gangguan di wilayah perbatasan seperti penyelundupan barang, senjata, narkotika dan penyelundupan manusia (Sudrajat, 2003).

Di perairan Indonesia beberapa isu yang sering terjadi di antaranya meliputi isu-isu terorisme, lalu lintas obat terlarang, perompakan dan pembajakan bersenjata di laut, penyelundupan senjata, penyelundupan orang, perdagangan wanita dan anak-anak, kejahatan illegal fishing yang sering dilakukan oleh ribuan kapal asing. Khusus masalah terakhir ini, Badan Pemeriksa Keuangan menunjukkan data potensi pendapatan sektor perikanan laut Indonesia jika tanpa illegal fishing mencapai Rp 365 triliun per tahun. Namun akibat illegal fishing, menurut perhitungan Kementerian Kelautan dan Perikanan pendapatan tersebut hanya berkisar Rp 65 triliun per tahun (Bakosurtanal, 2015). Sehingga setiap tahun Indonesia mengalami kerugian hingga ratusan triliun.

Dengan dibukanya jalur ALKI berarti mengharuskan Indonesia menjadi negara 'terbuka'. Posisi geografis yang serba terbuka dengan pintu masuk maupun pintu keluar yang menyebar di berbagai posisi akan memudahkan para pelaku pelanggaran di perairan Indonesia untuk melarikan diri menembus perairan bebas. Menerima status sebagai sebuah negara kepulauan dan sejumlah alur laut di dalamnya artinya pemerintah siap memanggul tanggung jawab memberikan jaminan keamanan laut dan udara dari segala bentuk gangguan dan ancaman. Kedaulatan dalam sebuah kesatuan negara kepulauan bukan hanya mencakup daratan dan laut saja tetapi juga ruang udara dalam teritorialnya. UNCLOS telah mengatur bahwa ruang udara adalah milik negara yang berada di bawahnya dan dapat dikelola serta dimanfaatkan bagi keuntungan negara tersebut. Jalur udara Indonesia sangat strategis, beribu-ribu maskapai internasional melintas di langit Indonesia setiap harinya. Hal ini menunjukkan wilayah udara Indonesia sebagai salah satu jalur terpadat di dunia. 
Jalur ALKI membuat posisi Indonesia menjadi penghubung antara dua lautan bebas karena letaknya yang memotong kesatuan wilayah kepulauan Indonesia dalam tiga bagian. ALKI sangat berharga bagi negara-negara luar kawasan dimana kepentingan utama mereka adalah kepastian akses serta ketersediaan sumber daya. Jalur ALKI dapat digunakan sebagaimana laut bebas bagi negara lain. Kapal-kapal asing termasuk kapal perang dapat melalui jalur tersebut tanpa harus meminta izin kepada pemerintah Indonesia. Kapal selam juga dapat melalui jalur ini tanpa wajib muncul ke permukaan laut. Begitu juga dengan pesawat yang dapat bebas melewati ruang udara dalam jalur ALKI. Setelah ALKI secara resmi diakui dalam peraturan pemerintah, perkembangan lingkungan strategis baik secara global, regional dan nasional menunjukkan adanya peningkatan aktivitas laut. Banyak negara maupun aktor bukan negara yang setiap hari beroperasi di dalam wilayah dan sekitar ALKI. Peningkatan aktivitas tersebut mendorong peningkatan potensi ancaman baik dari ancaman keamanan tradisional maupun nontradisional. Kepentingan negara-negara luar kawasan atas wilayah perairan Asia Tenggara juga perlu menjadi perhatian.

Beberapa negara yang aktivitasnya sangat bergantung dari perairan Indonesia diantaranya; Amerika Serikat (AS), dimana lebih dari 95 persen perdagangan luar negerinya adalah lewat laut (Fajriyansah, 2007:46). Perairan Indonesia menjadi jembatan yang menghubungkan AS dengan negara lain. Melihat berbagai potensi di Asia Pasifik, AS berusaha menunjukkan perannya dengan bergabung dalam Quadrilateral Security Partnership(QSP); sebuah kerjasama dalam bidang maritim dengan Australia, India, dan Jepang yang memiliki tujuan menghimpun kekuatan di kawasan untuk membendung manuver China dan Rusia di Asia Pasifik (Chellaney, 2010). Hal ini menyempurnakan keinginan AS untuk mengontrol dan mengendalikan Source Lines of Code (SLOC) yang terbentang dari Samudra Hindia hingga Laut Jepang (Soemantri, 2009:25), termasuk di dalamnya Choke Point ${ }^{1}$ penting di dunia yang berada di wilayah ALKI. AS juga mengalihkan pangkalan pertahanannya dari Okinawa ke Guam. Dengan alasan untuk mewujudkan fleksibilitas

\footnotetext{
${ }^{1}$ Yang dimaksud Choke Point disini ialah titik-titik penting dalam wilayah perairan yang didalamnya mengandung banyak sumber kekayaan laut. banyak negara memiliki kepentingan pada titik-titik tersebut. Di dunia terdapat sembilan Choke Point, empat diantaranya terdapat di perairan Indonesia. beberapa choke point strategis bagi kepentingan global tersebut ialah Selat Sunda, Selat Makassar-Lombok, Selat Malaka dan Perairan Ombai-Wetar.
} 
strategi, kebebasan dan kecepatan bertindak, peningkatan kemampuan deterrence, perang global terhadap terorisme, gelar penindakan untuk masa damai maupun untuk menghadapi kemungkinan perang serta respons terhadap situasi krisis yang terjadi di kawasan atau global. Kekuatan militer di Guam yang terdiri atas kekuatan Udara, Laut dan Marinir ini terus dikembangkan hingga mencapai sekitar 40.000 personel. Dari perspektif keamanan hal tersebut tentunya menjadi ancaman bagi Indonesia karena kekuatan besar telah berada tepat di depan pintu keluar masuk Choke Points Indonesia yaitu ALKI II. AS jelas menaruh perhatian khusus terhadap ALKI, bahkan hingga kini AS masih mendesak untuk dibukanya jalur ALKI baru yaitu ALKI timur-barat.

Negara selanjutnya yaitu China, yang telah mengklaim wilayah laut lepas yang mendekati Natuna dan telah mengembangkan Angkatan Lautnya menjadi kekuatan Blue Water Navy ke selatan hingga wilayah Asia Tenggara. Untuk memenuhi kebutuhan energi dan perdagangannya, China telah membeli beberapa kapal berukuran besar diantaranya kapal kontainer raksasa dan kapal tanker raksasa sebagai konsekuensi penggunaan kapal-kapal tersebut dibutuhkan pada alur perairan yang lebih dalam yaitu pada ALKI II dan ALKI III (Soemantri, 2009:27). China memang sangat membutuhkan jalur ALKI, terutama ALKI II yang menjadi lintas utamanya untuk melakukan perdagangan dengan Australia.

Berikutnya adalah Australia. Sudah menjadi rahasia umum bahwa Australia mempunyai berbagai kepentingan dalam wilayah perairan Indonesia. Keinginan Australia adalah menjadi penata keamanan kawasan sekaligus sebagai pemimpin negara-negara di Asia Pasifik. Oleh karena itu, selain AS, Australia adalah salah satu negara yang sangat berambisi untuk mengajukan pembukaan jalur ALKI baru, ALKI TimurBarat. $^{2}$ Keinginan pembukaan jalur ALKI baru yang belum terpenuhi ini memicu Australia beberapa kali melakukan pelanggaran wilayah laut maupun ruang udara Indonesia. Seperti pelanggaran perairan oleh kapal perang Australia terjadi pada 6 Januari 2013, dimana kapal perang

\footnotetext{
${ }^{2}$ ALKI Timur-Barat adalah jalur ALKI diajukan oleh Amerika Serikat dan Australia. Dari perspektif kepentingan nasional di laut, penetapan ALKI Timur-Barat memiliki implikasi yang lebih besar dibandingkan dengan ALKI Utara-Selatan, ALKI Timur-Barat terbentang dari Laut Arafuru sampai dengan Laut Jawa yang terhubung dengan alur laut kepulauan Indonesia (ALKI) I Utara-Selatan.
} 
Australia masuk ke perairan Indonesia hingga 7 mil dari pesisir Pulau Rote, Nusa Tenggara Timur (Jakarta, 2014).

Selain negara-negara maju, negara-negara dalam lingkup regional Asia tenggara juga memiliki kepentingan di perairan Indonesia. Penetapan batas secara delimitasi dan demarkasi baik di darat dan di laut sekali lagi masih menjadi pekerjaan rumah pemerintah Indonesia dengan sejumlah negara tetangga. Untuk pengendalian pelayaran di kawasan Asia Tenggara, Singapura hingga kini tetap keras menolak usulan Indonesia untuk mengalihkan sebagian lalu lintas pelayaran kapal berukuran besar dari Selat Malaka ke Selat Lombok atau Selat Makasar. Padahal jalur pelayaran di selat ini tidak hanya dipergunakan untuk armada niaga tetapi juga bagi kapal perang. Indonesia tentu akan terganggu apabila kapal-kapal perang dari dua negara yang sedang bertikai berpapasan di perairan Indonesia. Hingga kini, Indonesia baik dengan Singapura maupun Malaysia belum sampai pada sebuah kata sepakat untuk penentuan garis perbatasan wilayah laut. Dimana persoalan tersebut selalu memunculkan problematika pelanggaran wilayah kedaulatan berdasarkan persepsi masing-masing negara.

Kemudian persoalan laut dengan Thailand yang secara sepihak mengumumkan Zona Ekonomi Eksklusif berdasarkan Royal Proclamation tanggal 23 Februari 1981 berjarak 200 NM dari baselines Thailand dan mengusulkan landas kontinen dengan ZEE berhimpit. Padahal Indonesia berpendapat ZEE mempunyai rezim hukum yang berbeda dengan landas kontinen sesuai UNCLOS 1982 (Budiman, 2010).

Dengan Filipina, Indonesia mengusulkan diterapkannya prinsip proporsionalitas panjang pantai, dan median line bagi kawasan yang sempit. Filipina pertimbangkan masalah perikanan sebagai faktor yang relevan untuk mencari solusi yang equitable. Sejauh ini belum ada keputusan yang jelas mengenai batas maritim kedua negara kepulauan ini. Lalu, tantangan di perairan dekat Timor Leste, dimana ALKI melintas di wilayah negara tersebut yang memungkinkan tumpang tindih batas yuridiksi laut kedua negara (Budiman, 2010). Di perbatasan dengan Papua Nugini, belum ditetapkan luas daerah hukum tradisional nelayan dan bentuk maupun sifat kegiatannya (Budiman, 2010). Ancaman lain muncul pada status kepemilikan kepulauan Spartly dan Paracel yang diperebutkan oleh enam negara, yaitu China, Taiwan, Vietnam, Filipina, Malaysia dan Brunei Darussalam. Posisi kepulauan yang berada di pintu masuk ALKI ini akan berpengaruh pada situasi keamanan di Laut China 
Selatan serta berimplikasi pada situasi keamanan di wilayah ALKI I (Somantri, 2009).

Pembentukan ALKI membuat Indonesia 'dipotong-potong' secara imajiner yang memberikan peluang bagi kekuatan asing yang bermaksud mengancam keutuhan dan kesatuan Indonesia (Perwira Siswa Angkatan LXXIII, 2003). Ancaman keamanan laut akan terus meningkat intensitasnya apabila negara yang mempunyai kewenangan belum mampu menerapkan jaminan keamanan dan kepastian hukum untuk penegakan kedaulatan dan yurisdiksi negara di wilayah laut (Wahyu, 2010:90). Amat disayangkan apabila posisi geografis Indonesia yang penting ini belum dimanfaatkan secara maksimal.

\section{Menuju Poros Maritim Dunia di tengah Dilema ALKI}

ALKI sebagai jalur pelayaran dan penerbangan internasional telah terbentuk sejak diakuinya status Indonesia sebagai negara kepulauan. Konsekuensi dari sebuah negara yang terdiri dari gugusan pulau ialah harus mampu menerima permintaan dari negara lain melalui tahapan diplomasi untuk menyiapkan akses navigasi bagi kapal-kapal dan pesawat-pesawat asing yang ingin melintas. Indonesia dapat menolak kebijakan penambahan jalur ALKI baru seperti yang di kehendaki oleh negara lain. Sebaliknya, kemungkinan untuk mengurangi atau menutup jalur yang telah terbentuk dalam hal ini ALKI I, II dan III adalah hampir tidak mungkin. Upaya yang dapat dilakukan kemudian ialah mengelola dan memanfaatkan ALKI secara maksimal serta meminimalisir kegiatan ilegal dan berbagai bentuk pelanggaran yang terjadi didalamnya.

Pemerintah selaku pihak yang berwenang harus jeli memanfaatkan jalur ALKI, karena perairan Asia Tenggara merupakan satu diantara perairan dunia yang memiliki nilai strategis bagi kapal dagang dan jalur kapal yang melakukan kegiatan transit (Sakhuja, 2007:392). Idealnya, bila mampu menguasai dan memanfaatkan laut secara utuh akan mampu membawa Indonesia menjadi negara dengan pertahanan yang kuat. Apalagi abad ke-21 terjadi pertarungan economic resources yang kini mulai dominan di kawasan Asia. Pertarungan sumber-sumber ekonomi diprediksi dalam 10 hingga 15 tahun ke depan akan terjadi di lautan bukan lagi di daratan (Sukma, 2014). Untuk itu, Indonesia harus menyiapkan diri dan membenahi ruang-ruang peluang dalam setiap jangkau teritorial negara ini. Seharusnya, pemerintah Indonesia dapat memanfaatkan peluang pada ALKI untuk menggali keuntungan bagi perekonomian bangsa. Melalui tiga ALKI pemerintah bisa meraup 
pendapatan negara hingga miliaran rupiah setiap tahunnya. Seperti Singapura yang dapat memanfaatkan wilayah lautnya yang kecil secara maksimal, misalnya, negara ini mampu meraup devisa yang besar apabila terjadi sedikit pelanggaran pada wilayah perairannya.

Membaca dinamika dan tantangan pada jalur ALKI dan perairan sekitarnya, pemerintah perlu menyeimbangkan pengembangan gagasan poros maritim dengan peningkatan kualitas keamanan wilayah laut. Termasuk pada selat-selat yang digunakan untuk lintas damai seperti selat Malaka. Indonesia berpotensi untuk mengalami kerugian besar jika laut sebagai aset strategis tidak mendapatkan perlindungan secara maksimal. Perlu diperhatikan aspek pengawasan dan pengamanan utamanya terhadap kemungkinan infiltrasi dan subversi, termasuk didalamnya jaminan keamanan terhadap pengelolaan sumberdaya laut di sepanjang dan di sekitar ALKI. Implementasi dari konsep ketahanan nasional perlu diperhitungkan untuk menciptakan kondisi dinamis, terutama kesiapan dalam menghadapi segala bentuk ancaman dan gangguan pada seluruh wilayah perairan Indonesia.

Mencapai gagasan poros maritim dunia merupakan cita-cita yang rasional. Berkaca dari posisi geostrategi, geopolitik dan geoekonomi Indonesia yang sangat menguntungkan. Ide besar ini tidak berhenti pada pidato kampanye pemilihan presiden 2014 saja. Salah satu bentuk realisasi dari gagasan tersebut yang berhasil ditempuh oleh pemerintahan Jokowi ialah Indonesia dipercaya menjadi ketua dalam perhimpunan Asosiasi Negara-negara Samudera Hindia (IORA) yang beranggotakan 21 negara untuk masa kepemimpinan tahun 2015 hingga 2017 (Dahlan, 2015). Samudera Hindia merupakan salah satu pintu masuk ALKI yang memiliki potensi yang sangat prospektif. Kerjasama bidang ekonomi menjadi prioritas utama organisasi tersebut. Indonesia sebagai pemangku peran sentral diharapkan mampu membawa perubahan yang signifikan baik dalam kerjasama maupun peningkatan keamanan laut.

Mencapai cita-cita poros maritim memang membutuhkan waktu yang cukup lama, proses yang panjang dan kerjasama seluruh stake holder terkait. Menjaga tiga alur laut yang begitu luas terutama pada titik-titik pintu masuk dan keluar pelayaran internasional ke wilayah lautan Indonesia bukan hanya menjadi tugas pemerintah dan TNI, namun juga masyarakat secara umum, terutama nelayan dan masyarakat pesisir yang setiap hari hidup berdampingan dengan laut. Perjuangan untuk menjadi poros maritim dunia tentunya berimbas positif kepada penduduk di wilayah pantai dan pulau yang kehidupannya bergantung pada laut. Oleh 
karena itu, pemerintah perlu menopang dengan memberikan modal skill dan pendidikan dasar mengenai nilai bahari demi pemanfaatan hasil kelautan untuk tujuan jangka panjang. Dibutuhkan sinergisitas dari semua pihak yang mempunyai andil dalam menuju cita-cita poros maritim, serta dilengkapi juga dengan dukungan perangkat hukum yang tegas dimana perundang-undangan yang mengatur kewenangan masingmasing institusi penjaga keamanan laut terkelola dengan baik sehingga pelaksanaan pengelolaan keamanan laut dapat berjalan dengan efektif dan efisien.

Kemunculan potensi ancaman pada seluruh wilayah perairan Indonesia terutama pada ALKI setiap tahunnya harus menjadi catatan penting yang wajib di evaluasi. Sehingga dari sisi keamanan, postur pertahanan negara dapat menyiapkan porsi yang sesuai dengan kondisi dan kebutuhan untuk melindungi wilayah laut Indonesia. Kapabilitas kekuatan pertahanan harus didukung dengan ratusan armada canggih. Paling tidak Indonesia mempunyai armada yang mampu membuat para pelaku kejahatan menjadi 'was-was' untuk melakukan tindakan pelanggaran di perairan Indonesia, serta postur pertahanan yang kokoh sehingga membuat negara lain tidak memiliki keberanian untuk 'menyenggol' wilayah kedaulatan Indonesia. Sebagai negara besar Indonesia wajib menampilkan harga diri dan sikap yang tegas dengan menjadi pemain utama di kawasan demi terciptanya keamanan dan ketertiban kawasan. Dengan begitu Indonesia akan mampu menjamin keamanan maritim di perairan yurisdiksinya.

\section{Kesimpulan}

Berangkat dari pengalaman masa lalu dimana gagasan negara maritim Indonesia kerap berlalu sebagai wacana belaka, saat ini semua pihak berharap hal tersebut tidak terulang kembali. Upaya mewujudkan visi Indonesia sebagai 'Poros Maritim Dunia' perlu proses dan waktu yang tidak singkat. Memasuki rezim baru di bawah kepemimpinan Jokowi, cita-cita menjadi poros maritim dunia mendapatkan sambutan baik dari masyarakat. Jokowi datang sebagai pemimpin yang melanjutkan

perjuangan Ir. Juanda untuk memperjuangkan laut Indonesia dengan pemanfaatan ALKI dan kekayaan sumber daya laut yang dimiliki.

Beberapa hal yang patut digarisbawahi mengenai kebijakan pemerintah ke depan adalah sebagai berikut: Pertama, strategi mengedepankan kekuatan laut Indonesia terus dilakukan oleh semua instansi pemerintah yang berwenang pada wilayah perairan termasuk 
sejumlah departemen yang mempunyai andil di laut. Setiap unit wajib merumuskan program jangka pendek dan jangka panjang yang implementatif. Di samping itu, pemerintah harus bertindak tegas terhadap siapa saja manakala ada tindakan yang melanggar aturan hukum. Dalam beberapa bulan pemerintahan Jokowi, terlihat Kementerian Kelautan dan Perikanan (KKP) cukup tegas dan berani untuk mengontrol perkembangan laut Indonesia. KKP bekerja sama dengan aparat secara langsung memberikan sanksi kepada kapal asing yang mencuri ikan di perairan Indonesia.

Kedua, keberadaan jalur internasional yang membuat Indonesia menjadi negara terbuka tidak melulu menimbulkan masalah dan kerugian negara, sebagai bangsa yang cermat kita harus pandai memanfaatkan keadaan ALKI untuk meraup keuntungan. Ketiga, gagasan poros maritim hendaknya didukung dengan mengerahkan kekuatan mantra laut secara maksimal yang dibantu oleh pihak lain terkait seperti polisi air dan udara, pemerintah daerah, para nelayan, aktivis lingkungan, dan lain-lain. Keempat, menyusun rekomendasi langkah-langkah strategis dan implementatif yang didiskusikan bersama para ahli dalam masing-masing bidang. Indonesia wajib memperkuat status dari negara kepulauan menjadi negara maritim untuk pembangunan Indonesia yang berorientasi kelautan dalam rangka mewujudkan cita-cita sebagai poros maritim dunia.

\section{Daftar Pustaka}

Arsyad, R. (2010) Indonesia's Maritime and Security Interests in the New Era. In: Nguyen, Thang, ed. The Indonesian Journey: A Nation's Quest for Democracy, Stability and Prosperity. Nova Science Publishers, pp. 169-180.

Bakosurtanal (2015) Mewujudkan Indonesia Sebagai Poros Maritim Dunia yang Maju dan Mandiri [Online], Badan Informasi Geospasial. Tersedia dalam: $<$ http://www.bakosurtanal.go.id/berita-surta/show/mewujudkanindonesia-sebagai-poros-maritim-dunia-yang-maju-dan-mandiri> [Diakses 2 Mei 2015].

BPKP (1996) Undang-Undang Republik Indonesia Nomor 6 Tahun 1996 Tentang Perairan Indonesia [Online], Badan Pengawasan Keuangan dan Pembangunan. Tersedia dalam: <www.bpkp.go.id/uu/filedownload/2/47/476.bpkp> [Diakses 21 Mei 2014]. 
BPKP (2009) Undang Undang Republik Indonesia No.17 Th. 1985 tentang Pengesahan United Nations Convention On The Law Of The Sea (UNCLOS) 1982 [Online], Badan Pengawasan Keuangan dan Pembangunan, Tersedia dalam: <www.bpkp.go.id/uu/filedownload/2/26/101.bpkp> [Diakses 21 Mei 2014].

Budiman, A. (2010) (Kolonel CTP), Pembinaan Wilayah Negara Untuk Kepentingan Pertahanan [Online], Departemen Pertahanan. Tersedia dalam: $<$ http://buletinlitbang.dephan.go.id/ index.asp? vnomor=16\&mnorutisi=5>. [Diakses 21 Februari 2010].

Chellaney, B. (2010) Obstacles To Overcome In The Development Of A Concert Of Asia-Pacific Democracies [Online]. Tersedia dalam: http://chellaney.spaces.live.com/blog/cns!4913C7C8A2EA4A30!537.entry. [Diakses 21 Mei 2010].

Cipto, B. (2007) Hubungan Internasional di Asia Tenggara. Yogyakarta: Pustaka Pelajar.

Dahlan, F. (2015), Peran Indonesia memperkuat Kerjasama Di Kawasan Samudera India, [Online], Tabloid Diplomasi. Tersedia dalam: $<$ http://www.tabloiddiplomasi.org/current-issue/209-diplomasi-februari2015/1833-indian-ocean-rim-association-iora-peran-indonesiamemperkuat-kerjasama-di-kawasan-samudera-india.html> [Diakses 2 Mei 2015].

Fajriyansah, R. (2007) Perompakan Kapal Di Indonesia,Fakta Atau Konspirasi Opini? Surabaya: Java Pustaka Media Utama.

IMO (2010) Peta pengesahan ALKI [Online]. International Maritime Organization. Tersedia dalam: http://www.imo.org/includes/blastDataOnly.asp/data_id\%3D8751/200-a1ALKII-IIIAnnexVII.pdf. [Diakses 21 Mei 2010].

Irewati, A. (2011) Dinamika Perbatasan Wilayah Laut di Selat Malaka-Singapura, Jurnal Penelitian Politik LIPI, 8 (2), pp. 183-195.

Jakarta Greater (2014) Australia Terobos Perairan Indonesia [Online], Jakarta Greater National Guard. Tersedia dalam: $<$ http://jakartagreater.com/australia-terobos-perairan-indonesia/> [Diakses 3 Mei 2015].

Karim, M., Eksistensi Pulau-pulau Kecil di Kawasan Perbatasan Negara, [Online]. Tersedia dalam: $<$ http://bulletin.penataanruang.net/index.asp?buled=42> [Diakses $21 \mathrm{Mei}$ 2010].

Marsetio (Januari 2015) Aktualisasi Peran Pengawasan Wilayah Laut Dalam Mendukung Pembangunan Indonesia Sebagai Negara Maritim Yang Tangguh, disampaikan pada acara Kuliah Umum di hadapan Civitas Akademika Universitas Sumatera Utara,Medan. 
Perwira Siswa Angkatan LXXIII (2003). Optimalisasi Kemampuan Pengamatan Dan Pengintaian Tni Angkatan Udara Di Wilayah ALKI Dalam Rangka Meningkatkan Pertahanan Nasional Pada Masa Lima Tahun Mendatang, Naskah angkatan Komando Pendidikan Angkatan Udara Sekolah Komando Kesatuan, Jakarta.

Prasetyono, E. (2008) Strategi Pertahanan Indonesia di Masa Depan. Analisis CSIS, 37 (3), pp. 347-361.

Presiden Republik Indonesia (2002) Peraturan Pemerintah Republik Indonesia No. 38 tahun 2002 Tentang Daftar Ordinat Geografis Titik-titik Garis Pangkal Kepulauan Indonesia [Online]. Kementerian Energi dan Sumber Data Manusia. Tersedia dalam : <prokum.esdm.go.id/pp/2002/pp_38_2002.pdf> [Diakses 5 Juni 2010].

Rahakundini, C. (2015) Kekuatan Maritim Indonesia Keenam Terbesar Asia Pada 2020, [Online], Jurnal Maritim. Tersedia dalam: $<$ http://www.jurnalmaritim.com /2015/05/kekuatan-militer-indonesiakeenam-terbesar-asia-pada-2020/> [Diakses 2 Mei 2015].

Sakhuja, V. (Agustus 2007) Maritime Security in Southeast Asia, Contemporary Southeast Asia, 29 (2).

Setneg (2009) Indonesia Tuan Rumah 3 Kegiatan Kelautan Internasional [Online], Kementerian Sekretariat Negara Republik Indonesia. Tersedia dalam: $<$ http://www.setneg.go.id/index.php?option=com_content\&task=view\&id $=3266>$ [Diakses 2 Mei 2015].

Sitohang, J, et al. (2008) Perbatasan Wilayah Laut Indonesia di Laut China Selatan: Kepentingan Indonesia di Perairan Natuna. Jakarta: LIPI Press.

Somantri, D. (2009) Optimalisasi Gelar Kekuatan TNI AL Guna Pengamanan ALKI Dalam Rangka Mendukung Penegakan Kedaulatan NKRI. Markas Besar Angkatan Laut, Sekolah Staf dan Komando, Jakarta.

Sudrajat (Juli 2003) Perubahan Wajah Ancaman dan Keamanan Domestik Indonesia, makalah disampaikan pada Seminar dan Lokakarya "Pembangunan Hukum Nasional VIII", Badan Pembinaan Hukum Nasional, Departemen Kehakiman dan Hak Asasi Manusia, Denpasar.

Sukma, R. (2014) Gagasan Poros Maritim, Kompas, 21 Agustus 2014.

Sukma, R. (2014) Gagas Poros Maritim Dunia, Jokowi Sadari Masa Depan Ada di Laut [Online]. Kompas. Tersedia dalam: $<$ http://bisniskeuangan.kompas.com/read/

2014/07/05/205320526/Gagas.Poros.

Maritim.Dunia.Jokowi.Sadari.Masa.Depan.Ada.di.Laut> [Diakses 2 Mei 2015].

Tempo (2014) Cara Jokowi Jadikan Indonesia Poros Maritim [Online], Tempo. Tersedia

dalam: <http://www.tempo.co/read/news/2014/11/13/118621707/Cara-JokowiJadikan-Indonesia-Poros-Maritim> [Diakses 2 Mei 2015]. 
Usman, S \& Isnawita (2009) Heboh Ambalat, Ternyata Malaysia Ingin Merebut Sumber Minyak Indonesia, Narasi, Yogyakarta

Victor, S. (2014) Indonesia Menuju Poros Maritim Dunia, Pusat Pengkajian, Pengolahan Data dan Informasi (P3DI) Sekretariat Jenderal DPR RI, VI (I) (21) Jakarta.

Wahyu, F., (2013) Potensi Kedaulatan Maritim Sebagai Posisi Tawar Dalam Diplomasi Indonesia, disampaikan pada seminar 'Refleksi 65 tahun Politik Luar Negeri Indonesia Bebas Aktif', Yogyakarta, pp. 83-91.

Wahyono, S.K. (2007) Indonesia Negara Maritim. Jakarta: Teraju (Anggota IKAPI). 
Indonesian Perspective, Vol 1 No. 1 (Januari-Juni): 1-21 